\title{
Autonomia Privada Coletiva como Instrumento de Violação dos Direitos Fundamentais Sociais dos Trabalhadores, de Graziela Colombari
}

\section{Book Review}

Rodrigo Wasem Galia ${ }^{1}$

\section{A obra "Autonomia Privada Coletiva como Instrumento de Violação} dos Direitos Fundamentais Sociais dos Trabalhadores", de autoria de Graziela Colombari, é obra de suma importância no atual cenário brasileiro de precarização das relações de trabalho após a Reforma Trabalhista operada pela Lei $\mathrm{n}^{\circ} 13.467 / 2017$, em que o negociado prevalece sobre o legislado, a teor do art. 611-A da CLT. A obra, nesse sentido, analisa a fundo a autonomia privada coletiva, reconhecida na Constituição Federal em seu artigo $7^{\circ}$, XXVI, como instrumento de violação dos direitos fundamentais dos trabalhadores. Sim, porque aquilo que é pactuado coletivamente opera efeitos jurídicos nos respectivos contratos de trabalho dos empregados representados nesses instrumentos coletivos. É o chamado princípio da autodeterminação coletiva.

Se, no direito coletivo do trabalho, os entes sindicais possuem a prerrogativa de criarem normas sem a interferência do Poder Legislativo via negociações coletivas, são realizados instrumentos que possuem força de lei para as partes contratantes (sindicatos, empregadores e

\footnotetext{
1 Professor do Mestrado em Direito da Universidade Federal de Santa Maria. Professor Adjunto de Direito do Trabalho, Direito Processual do Trabalho e de Direito Previdenciário do Curso de Direito da Universidade Federal de Santa Maria. Professor Convidado das PósGraduações em Direito do Trabalho e em Direito Processual do Trabalho da PUCRS, Verbo Jurídico, ambas em Porto Alegre - RS, e da UNISC - em Santa Cruz do Sul - RS e da Unochapecó, em Chapecó - SC. Pós-Doutor em Direito pela PUCRS (2019). Doutor em Direito pela PUCRS, aprovado com votos de louvor e distinção (2016). Mestre em Direito pela PUCRS (2004). Bacharel em Direito pela PUCRS (1999).
} 
trabalhadores). Assim, o exercício da Autonomia Privada Coletiva na criação de normas podem trazer tanto benefícios como malefícios nas condições de trabalho das categoriais profissionais (sindicatos de trabalhadores).

Portanto, a pesquisa tão bem levada a cabo por Graziela, analisa o comportamento das instituições sindicais frente aos processos impostos pela globalização e a crise enfrentada no mundo do trabalho, verificando casos concretos de violações de direitos fundamentais em razão das negociações coletivas, bem como a atuação do judiciário frente ao problema apresentado. Nesse contexto, a autonomia privada como poder de criar normas autônomas, contribui para o pluralismo jurídico, que por sua vez, contempla, no ordenamento jurídico, as normas heterônomas, produzidas pelo Estado e as normas autônomas, decorrentes da composição realizada entre as forças do capital e trabalho.

Se por um lado, a elaboração autônoma da norma produz a modernização da legislação trabalhista e é acompanhada dos problemas que surgem com o direito contemporâneo do trabalho; por outro, acaba, em certos momentos, sendo utilizada como forma de violar direitos dos trabalhadores. Fala-se assim, do uso indiscriminado da flexibilização do trabalho, que frisa-se, é autorizada em casos expressos pela Constituição Federal, mas em certos momentos é utilizada de forma desvirtuada. Neste contexto, diversas são as explicações para o que atualmente representa a atuação das instituições sindicais. Passam pela globalização, transformações do mundo do trabalho e até mesmo pela crise de ética e legitimidade enfrentadas pelos atores sociais.

Antes da Reforma Trabalhista, era inválida a negociação coletiva que reduzisse o intervalo mínimo intrajornada, uma vez que, este constituía norma de saúde e segurança do trabalho, a teor da Súmula 437, I, do TST. Mas após o advento da Lei 13.467/2017, que introduziu o art. 611-A, inciso III, da CLT, a negociação coletiva (convenção coletiva e o acordo coletivo de 
trabalho) tem prevalência sobre a lei quando, entre outros, dispuser sobre intervalo intrajornada, respeitado o limite mínimo de trinta minutos para jornadas superiores a seis horas. Não se pode vislumbrar justiça no caso de um trabalhador ter apenas trinta minutos de intervalo em uma jornada superior a seis horas diárias de labor. Isso não é benéfico à sua saúde e à sua integridade física. Não se deveria poder afastar a natureza protetiva do Direito do Trabalho sobre a saúde do trabalhador no que tange a normas de duração do trabalho (jornada de trabalho) via negociação coletiva.

Graziela, jurista preocupada com a efetivação dos direitos fundamentais sociais, é da nova safra de estudiosos do Direito do Trabalho comprometidos com a defesa do trabalhador, hipossuficiente nas relações de trabalho. Embora a obra seja anterior à Reforma Trabalhista, a autora já se preocupava com a flexibilização, ou seja, retirada de direitos trabalhistas garantidos lá no Direito Individual do Trabalho (núcleo duro de direitos e garantias trabalhistas) pelo Direito Coletivo do Trabalho (núcleo flexível de direitos e garantias trabalhistas).

Parecia adivinhar que os instrumentos normativos coletivos oriundos da negociação coletiva viriam para violar os direitos fundamentais sociais dos trabalhadores. Esta é a magia que surge da leitura da obra, indispensável aos operadores do Direito, que buscam assegurar àqueles que vendem sua força de trabalho, uma existência digna no embate entre o valor social do trabalho e a livre iniciativa.

\section{Referências}

COLOMBARI, G. . Autonomia Privada Coletiva como Instrumento de Violação dos Direitos Fundamentais dos Trabalhadores.. Uberlândia: Navegando Publicações, 2017. $154 \mathrm{p}$.

Artigo recebido em: 30/09/2019.

Aceito para publicação em: 19/11/2019. 